\title{
Inhibition of Oxidative Stress and ALOX12 and NF-KB Pathways Contribute to the Protective Effect of Baicalein on Carbon Tetrachloride-Induced Acute Liver Injury
}

\author{
Chongshan Dai ${ }^{1,2, * \mathbb{C}}$, Hui Li ${ }^{3}$, Yang Wang ${ }^{1,2}$, Shusheng Tang ${ }^{1,2}$, Tony Velkov $4, * \mathbb{C}$ and Jianzhong Shen ${ }^{1,2}$ \\ 1 College of Veterinary Medicine, China Agricultural University, No. 2 Yuanmingyuan West Road, \\ Beijing 100193, China; wangyang@cau.edu.cn (Y.W.); tssfj@cau.edu.cn (S.T.); sjz@cau.edu.cn (J.S.) \\ 2 Beijing Key Laboratory of Detection Technology for Animal-Derived Food Safety, College of Veterinary \\ Medicine, China Agricultural University, Beijing 100193, China \\ 3 Beijing Key Laboratory of Diagnostic and Traceability Technologies for Food Poisoning, Beijing Center for \\ Disease Prevention and Control, Beijing 100193, China; lihui@bjcdc.org \\ 4 Department of Pharmacology \& Therapeutics, School of Biomedical Sciences, Faculty of Medicine, Dentistry \\ and Health Sciences, The University of Melbourne, Parkville, VIC 3010, Australia \\ * Correspondence: daichongshan@cau.edu.cn (C.D.); tony.velkov@unimelb.edu.au (T.V.)
}

\section{check for}

updates

Citation: Dai, C.; Li, H.; Wang, Y.; Tang, S.; Velkov, T.; Shen, J. Inhibition of Oxidative Stress and ALOX12 and NF- $\kappa$ B Pathways Contribute to the Protective Effect of Baicalein on Carbon Tetrachloride-Induced Acute Liver Injury. Antioxidants 2021, 10, 976. https://doi.org/10.3390/ antiox10060976

Academic Editors: Anna Maria Fratta Pasini and Luciano Cominacini

Received: 24 April 2021

Accepted: 11 June 2021

Published: 18 June 2021

Publisher's Note: MDPI stays neutral with regard to jurisdictional claims in published maps and institutional affiliations.

Copyright: (c) 2021 by the authors. Licensee MDPI, Basel, Switzerland. This article is an open access article distributed under the terms and conditions of the Creative Commons Attribution (CC BY) license (https:// creativecommons.org/licenses/by/ $4.0 /)$.

\begin{abstract}
This study investigates the protective effect of baicalein on carbon tetrachloride $\left(\mathrm{CCl}_{4}\right)$-induced acute liver injury and the underlying molecular mechanisms. Mice were orally administrated baicalein at 25 and $100 \mathrm{mg} / \mathrm{kg} /$ day for 7 consecutive days or ferrostatin-1 (Fer-1) at $10 \mathrm{mg} / \mathrm{kg}$ was i.p. injected in mice at 2 and $24 \mathrm{~h}$ prior to $\mathrm{CCl}_{4}$ injection or the vehicle. Our results showed that baicalein or Fer-1 supplementation significantly attenuated $\mathrm{CCl}_{4}$ exposure-induced elevations of serum alanine aminotransferase and aspartate aminotransferase, and malondialdehyde levels in the liver tissues and unregulated glutathione levels. Baicalein treatment inhibited the nuclear factor kappa-B (NF-kB) pathway, activated the erythroid 2-related factor 2 (Nrf2)/heme oxygenase 1 (HO-1) pathway in liver tissues, and markedly improved $\mathrm{CCl}_{4}$-induced apoptosis, inflammation and ferroptosis in liver tissues exposed with $\mathrm{CCl}_{4}$. In vitro, baicalein treatment improved $\mathrm{CCl}_{4}$-induced decreases of cell viabilities and knockdown of Nrf2 and arachidonate 12-lipoxygenase (ALOX12) genes partly abolished the protective effect of baicalein on $\mathrm{CCl}_{4}$-induced cytotoxicity in HepG2 cells. In conclusion, our results reveal that baicalein supplementation ameliorates $\mathrm{CCl}_{4}$-induced acute liver injury in mice by upregulating the antioxidant defense pathways and downregulating oxidative stress, apoptosis, inflammation and ferroptosis, which involved the activation of Nrf2 pathway and the inhibition of ALOX12 and NF-kB pathways.
\end{abstract}

Keywords: baicalein; oxidative stress; ferroptosis; acute liver injury; ALOX12 pathway; Nrf2 pathway

\section{Introduction}

Over the past several decades, liver disease has been consistently on the rise, so much so that it has become one of the leading causes of mortality and morbidity worldwide [1]. Currently, approved drugs for treating liver injury usually have many side-effects and limited efficacy [2], such that to date, safer, effective hepatoprotective drugs remain an unmet medical need.

Drugs, chemicals or alcohol-caused acute liver injury are common in most countries and serious liver injury often leads to liver failure, and even death [3]. The pathology of acute liver injury involves necrosis, infiltration of inflammatory cells and apoptosis [4-7]. Carbon tetrachloride $\left(\mathrm{CCl}_{4}\right)$ is commonly used as the inducing agent in animal models of acute injury liver (e.g., mice, rats or rabbits), which are commonly employed to identify or screen for hepatoprotective agents [4-7]. It is well known that $\mathrm{CCl}_{4}$ is metabolized by the liver cytochrome P4502E1, which leads to the production of highly reactive trichloromethyl free radicals and excessive reactive oxygen species (ROS) [8]. It is well known that excessive ROS production damages intracellular macromolecules (e.g., lipids, proteins, and DNA) and 
leads to lipid peroxidation and oxidative stress; the two biochemical hall marks of acute liver injury [9-12]. $\mathrm{CCl}_{4}$ exposure induces necrosis, apoptosis and inflammatory responses in hepatocytes via several pathways, including the activation of autophagy, p53, toll-like receptor 4 (TLR4), mitogen-activated protein kinase (MAPK), and transforming growth factor- $\beta 1$ (TGF- $\beta 1$ ) pathways [13-15]. $\mathrm{CCl}_{4}$ exposure can also up-regulate the nuclear factorkappaB (NF-kB)-mediated inflammatory response, which leads to the release and expression of tumor necrosis factor-alpha (TNF- $\alpha$ ), high mobility group box-1 protein 1 (HMGB1), interleukin-1 $\beta$ (IL-1 $\beta$ ), IL-6, and inducible nitric oxide synthase (iNOS) [13-16]. Notably, we have previously shown that the up-regulation of cellular anti-oxidant systems (superoxide dismutase [SOD], and catalase [CAT] and production of glutathione [GSH]), ameliorates $\mathrm{CCl}_{4}$-induced acute liver injury $[13,15,17]$. Recent studies revealed that ferroptosis, a form of regulated cell death, may be a key player in acute liver injury. Ferroptosis is characterized by the iron-dependent accumulation of lipid hydroperoxides to lethal cellular levels [18]. The up-regulated expression of cyclooxygenase-2 (COX-2), increased of malondialdehyde (MDA) levels and depletion of glutathione (GSH) levels are considered as the major biomarkers of ferroptosis [18]. $\mathrm{CCl}_{4}$ exposure-induced acute liver injury involves a similar pathology as well as increased levels of monounsaturated and polyunsaturated fatty acids (PUFA) [19]. In line with these findings, ferroptosis inhibitors (e.g., $\mathrm{N}$-acetylcysteine (NAC) and deferoxamine (DFO) were shown to effectively improve $\mathrm{CCl}_{4}$-induced acute liver injury or liver fibrosis in rats $[20,21]$.

Herbal antioxidants are attractive therapeutic alternatives for preventing or treating acute liver injury due to their higher efficiency and low incidence of adverse effects [2]. Baicalein (5,6,7-trihydroxy-2-phenylchromen-4-one; Figure 1), is a nature product from the root of Scutellaria baicalensis. It has many beneficial pharmacological activities, including anti-inflammatory, anti-oxidative, anti-macrobiotic and immuno-regulatory [22]. Baicalein has a time-honored place in Asian traditional medicine for treating liver, renal and cardiovascular diseases [23-25]. Available evidences suggests that the baicalein supplementation can attenuate cisplatin-induced hepato- and nephro-toxicity, via the attenuation of oxidative stress, apoptosis, and inflammatory responses [23,26]. A highthroughput screen from a natural product library containing 1130 chemicals showed that baicalein had highest inhibitory effects on acute liver injury induced lipopolysaccharides (LPS)/Dgalactosamine (D-gal) in vitro [27]. In the present study, we investigated the protective effects of baicalein supplementation on $\mathrm{CCl}_{4}$-induced acute liver injury and the underlying molecular mechanisms both in vivo and in vitro. We assume that inhibition of oxidative stress, inflammation, and arachidonate 12-lipoxygenase (ALOX12) and NF- $\mathrm{B}$ pathways contributed to the protective effect of baicalein on carbon tetrachloride-acute induced liver injury.<smiles>O=c1cc(-c2ccccc2)oc2cc(O)c(O)c(O)c12</smiles>

Figure 1. The chemical structure of baicalein.

\section{Materials and Methods}

\subsection{Chemicals and Reagents}

Baicalein (purity $\geq 98 \%$ ) was purchased from Aladdin Reagent Co., Ltd. (Shanghai, China). Phenylmethylsulfonyl fluoride (PDMSF) was purchased from Sigma (St. Louis, $\mathrm{MO}$, USA). $\mathrm{CCl}_{4}$ was purchased from Kaixing Chemical Industry Co., Ltd. (Tianjin, China). Ferrostatin-1 (Fer-1) was purchased from Cayman Chemicals (Ann Arbor, MI, USA). Erastin 
was purchased from Selleck Chemicals (Shanghai, China). All other reagents were of the highest analytical reagent grade available.

\subsection{Animals, Treatments and Experimental Design}

The Institutional Animal Care and Use Committee at the China Agricultural University approved all animal experiments in this study. Male C57 BL/ 6 mice ( 8 weeks old, 20-22 g) were purchased from Vital River Animal Technology Co., Ltd. (Beijing, China). An acclimation period of one week for all animals was performed. Mice were housed in a room maintained under the following conditions: at a temperature of $22 \pm 3{ }^{\circ} \mathrm{C}$ and relative humidity of $55 \pm 5 \%$ and a 12-h light-dark cycle. During the experiments, all mice had free access to food and water. In all animal experiments, mice were euthanized by intraperitoneal injection of an overdose of sodium pentobarbital $(80 \mathrm{mg} / \mathrm{kg})($ Sigma, St. Louis, MO, USA).

\subsubsection{Gene and Protein Expression in the Liver Tissues of Mice Exposed $\mathrm{CCl}_{4}$}

To investigate the gene and protein expressions in the liver tissues after $\mathrm{CCl}_{4}$ exposure, eight mice were intraperitoneally (i.p) injected with $0.3 \% \mathrm{CCl}_{4}(10 \mathrm{~mL} / \mathrm{kg}$, dissolved in olive oil). The mice in the control group were i.p. injected with an equal volume of the olive oil vehicle. At 6 and $24 \mathrm{~h}$, mice were sacrificed (4 mice were in each time point) and liver tissues were collected. Key genes and protein as the biomarkers of apoptosis (Bax, GADD45a, MAPK7, and p21), inflammation (NF- $\kappa B$, TNF-a, IL1 $\beta, I L-6$, and iNOS), and ferroptosis (GPX1, GPX4, ALOX12, SCD1, and COX-2) pathways were selected and examined.

\subsubsection{Effect of Baicalein Supplementation on $\mathrm{CCl}_{4}$-Induced Acute Liver Injury}

To investigate the protective effect of baicalein supplementation on $\mathrm{CCl}_{4}$-induced acute liver injury, sixty mice were randomly divided into six groups (10 mice were in each group): (1) untreated control, (2) baicalein $25 \mathrm{mg} / \mathrm{kg} /$ day (designated Bai 25), baicalein $100 \mathrm{mg} / \mathrm{kg} /$ day (designated Bai 100), (4) $\mathrm{CCl}_{4}$ only, (designated $\mathrm{CCl}_{4}$ ) (5) $\mathrm{CCl}_{4}$ plus baicalein $25 \mathrm{mg} / \mathrm{kg}$ /day (designated $\mathrm{CCl}_{4}+$ Bai 25) and (6) $\mathrm{CCl}_{4}$ plus baicalein $100 \mathrm{mg} / \mathrm{kg} /$ day (designated $\mathrm{CCl}_{4}+$ Bai 100). Baicalein was dissolved in $0.5 \%$ sodium carboxymethyl cellulose (CMC-Na) and orally administrated to mice at $25 \mathrm{mg} / \mathrm{kg}$ or $100 \mathrm{mg} / \mathrm{kg}$ per day for 7 consecutive days, which was accorded to the previous published studies [28,29]; the mice in the control group were treated with an equal volume of $0.5 \%$ CMC-Na. After final administration, the mice in the $\mathrm{CCl}_{4}+\mathrm{Bai} 25 ; \mathrm{CCl}_{4}+\mathrm{Bai} 100 ;$ and $\mathrm{CCl}_{4}$ only groups were injected intraperitoneally (i.p.) with $0.3 \% \mathrm{CCl}_{4}(10 \mathrm{~mL} / \mathrm{kg}$, dissolved in olive oil). The control and baicalein alone groups (i.e., Bai 25 and Bai 100) were i.p. administered with an equal volume of the olive oil vehicle only. Following $24 \mathrm{~h}$ after $\mathrm{CCl}_{4}$ challenge, mice were sacrificed; blood was collected and serum alanine aminotransferase (ALT) and aspartate aminotransferase (AST) were evaluated. The liver samples were collected for histopathological and biochemical assessments including the biomarkers of oxidative stress, apoptosis staining, and gene expression.

\subsubsection{Ferroptosis in Liver Acute Injury}

To investigate the role of ferroptosis in $\mathrm{CCl}_{4}$-induced acute liver injury, mice were co-administered Fer-1, a potent and selective inhibitor of ferroptosis [30]. Twenty-four mice were randomly divided into 4 groups (6 mice in each group): (1) control, (2) Fer-1, (3) $\mathrm{CCl}_{4}$, and (4) $\mathrm{CCl}_{4}$ plus Fer-1 $\left(\mathrm{CCl}_{4}+\right.$ Fer-1). The dose of Fer-1 is accorded to the Yamada et al. study with minor revision [31]. Fer-1 were i.p. injected at $10 \mathrm{mg} / \mathrm{kg}$ to mice for 2 times before $\mathrm{CCl}_{4}$ exposure, i.e., at $24 \mathrm{~h}$ and $2 \mathrm{~h}$ prior to $\mathrm{CCl}_{4}$ exposure. At $24 \mathrm{~h}$ post $\mathrm{CCl}_{4}$ challenge, blood and liver samples were harvested. The levels of AST and ALT, and histopathological changes, were evaluated. 


\subsection{In Vivo Animal Experiment and Measurement}

\subsubsection{Levels of ALT and AST}

Blood samples from mice were centrifuged at $3000 \times g$ for $10 \mathrm{~min}$ for biochemical analysis, according to a previously published paper with minor revision [32]. Serum alanine aminotransferase (ALT) and aspartate aminotransferase (AST) activities were measured using an automatic analyzer (Hitachi 7080, Hitachi High-Technologies Corporation, Tokyo, Japan).

\subsubsection{Histopathological Examination of Liver Tissues}

Liver tissues from four mice were isolated and fixed in $10 \%$ neutral buffered formalin for at least $48 \mathrm{~h}$, then sectioned and histopathological analysis were performed as described below [15]. In brief, the liver slices were cut into $4 \mu \mathrm{m}$-thick sections and stained with hematoxylin-eosin. A semi-quantitative score (SQS) system was used to analyze the histopathological damage: Grade 0 showed no marked pathological change. Grade 1 showed the presence of hepatocyte degeneration with small rare of foci of necrosis. Grade 2 showed the small area of mild centrilobular necrosis around the central vein. Grade 3 showed the area of mild centrilobular necrosis that is severer than Grade 2. Grade 4 showed the centrilobular necrosis that is severer than Grade 3.

\subsubsection{Measurement for Antioxidant Markers}

Approximately $100 \mathrm{mg}$ of liver tissue was homogenized in $1 \mathrm{~mL}$ of cold Tris buffer to prepare a $10 \%$ tissue homogenate, according to previous published paper with minor revision [32]. Then, the homogenates were centrifuged at $3000 \times g$ for $15 \mathrm{~min}$ at $4{ }^{\circ} \mathrm{C}$. The supernatant was collected for the measurement of the levels of MDA, nitric oxide (NO) and reduced glutathione (shown as GSH) and activities of iNOS (Beyotime, Haimen, China), CAT, and SOD using commercial kits as per the manufacturer's instructions (Nanjing Jiancheng Institute of Biological Engineering, Nanjing, China), respectively.

\subsubsection{Measurement of $I L-1 \beta, T N F-\alpha$, and IL-6 Levels in Liver Tissues}

The levels of TNF- $a, I L-1 \beta$ and $I L-6$ in the liver tissues were determined by using TNF- $a$, $I L-1 \beta$ and $I L-6$ ELISA kits according to the manufacturer's instructions (R\&D Systems, Minneapolis, MN, USA).

\subsubsection{Measurements of Caspase- 9 and -3 Activities}

Approximately $10 \mathrm{mg}$ of liver tissue was lysed using the commercially supplied cold lysis buffer (about $0.5 \mathrm{~mL}$ ) for $15 \mathrm{~min}$. The lysates were centrifuged at $12,000 \times g$ for $10 \mathrm{~min}$ at $4{ }^{\circ} \mathrm{C}$ and the supernatants were collected. The activities of caspase- 3 and caspase- 9 were measured using commercial caspase- 3 and caspase-9 kits according to the manufacturer's instructions (Beyotime, Haimen, China). The activities were normalized to the value for the untreated control samples.

\subsubsection{Measurements of Apoptosis in the Liver Tissues}

The apoptosis rates in the liver slices were measured using a deoxynucleotidyl transferase-mediated dUTP nick-end labeling (TUNEL) kits (Vazyme Biotech Co., Ltd., Nanjing, China) and 4'-6-diamidino-2-phenylindole (DAPI) was used to label the cell nuclei.

\subsubsection{Quantitative Reverse-Transcription (qRT) PCR Examination}

Gene expression analysis were performed by qRT-PCR. In brief, total RNA was isolated using the TRIzol extraction method (Invitrogen Inc, Carlsbad, CA, USA). The quality of isolated RNA was evaluated by the optical density at $260 / 280 \mathrm{~nm}$ (all values are between 1.9 2.1). Approximately $500 \mathrm{ng}$ of total RNA was subjected to reverse transcription to produce cDNA by using the Prime Script RT-PCR kit (Takara, Dalian, China). The detail primer information is documented in Supplementary Table S1. $\beta$-actin was used 
as an internal control, and $2^{-\Delta \Delta C t}$ method was used to calculate the fold change of gene expression.

\subsubsection{Western Blotting}

Mouse liver tissue of 10-20 mg was homogenized using a Dounce homogenizer in $500 \mu \mathrm{L}$ ice-cold lysis buffer ( $100 \mathrm{mM}$ Tris- $\mathrm{HCl}, 2 \%(w / v)$ sodium dodecyl sulfate (SDS), $10 \%(v / v)$ glycerol, $\mathrm{pH} 7.4)$ with a protease inhibitor cocktail $(1 \mu \mathrm{g} / \mathrm{mL}$ aprotinin, $1 \mu \mathrm{g} / \mathrm{mL}$ leupeptin, $1 \mu \mathrm{g} / \mathrm{mL}$ pepstatin A and $1 \mathrm{mM}$ PMSF). Tissue lysate samples were centrifuged at $12,000 \times \mathrm{g}$ for $15 \mathrm{~min}$ at $4{ }^{\circ} \mathrm{C}$, and the protein concentration was measured using a bicinchonininc acid (BCA) protein assay kit. Equal amounts of protein from each sample were resolved by sodium dodecyl sulfate-polyacrylamide gel electrophoresis (SDS-PAGE) and transferred to nitrocellulose membranes (Bio-Rad, Hemel Hempstead, UK). The following primary antibodies were used to probe the membranes: primary rabbit antibodies against p21 (1:1000), COX2 (1:1000), Nrf2 (1:1000), and HO-1 (1:1000) (ProteinTech Group, Inc., Chicago, IL, USA), mouse monoclonal antibody against ALOX12 (1:1000) (Abcam, Cabridge, MA, USA) and $\beta$-actin (1:1000) (Santa Cruz Biotechnology, Dallas, TX, USA). Membranes were incubated overnight with the primary antibodies, followed by developing with secondary antibodies (1:5000) for $1 \mathrm{~h}$ at room temperature. The results were quantified by densitometry using Image J software, and normalized relative to the $\beta$-actin bands.

\subsection{Cell Culture, Treatment and Measument}

\subsubsection{Cell Culture}

The human HepG2 cell line was purchased from the Cell Bank of the Chinese Academy of Sciences (Shanghai, China). HepG2 cells were cultured in Dulbecco's modified Eagle's medium (DMEM) medium (Life Technologies Corporation, Grand Island, NY, USA) containing $10 \%(v / v)$ heat-inactivated fetal bovine serum (FBS), 100 units $/ \mathrm{mL}$ penicillin, $110 \mathrm{mg} / \mathrm{L}$ sodium pyruvate, and $100 \mu \mathrm{g} / \mathrm{mL}$ streptomycin (Beyotime, Haimen, China) and maintained in a humidified atmosphere of $95 \%$ air and $5 \% \mathrm{CO}_{2}$ at $37{ }^{\circ} \mathrm{C}$.

\subsubsection{Gene Knockdown by siRNA}

HepG2 cells were transfected with siRNA oligos (Sigma, St. Louis, MO, USA) that targeted Nrf2 and ALOX12 using Lipofectamine RNAiMAX (ThermoFisher, Cabridge, MA, USA) in Opti-MEM ${ }^{\mathrm{TM}}$ for $6 \mathrm{~h}$. The medium was then replaced by fresh DMEM for additional $24 \mathrm{~h}$. For each targeted gene, two commercial siRNA oligos were employed: Nrf2: SiRNA\#1, SASI_Hs01_00182393; SiRNA\#2, SASI_Hs02_00341015; ALOX12: SiRNA\#1, SASI_Hs02_00303100; SiRNA\#2, SASI_Hs02_00303101. Mission siRNA universal negative control \#1 (Sigma, St. Louis, MO, USA) was used as a negative control. Various treatments were performed at $24 \mathrm{~h}$ after knockdown. To confirm the effectiveness of siRNA, the expressions in the levels of mRNA and protein were measured by using qRT-PCR and Western blotting.

\subsubsection{Measurement of Cell Viability}

HepG2 cells were seeded in 96-well plate $\left(1 \times 10^{5}\right.$ cells/well $)$ for $12 \mathrm{~h}$, then cells were pretreated with baicalein at 10 and $20 \mu \mathrm{M}$ for $2 \mathrm{~h}$, or knockdown with Nrf2 or ALOX12 genes, respectively, then treated with $10 \mu \mathrm{M}$ erastin or $0.4 \% \mathrm{CCl}_{4}$ for additional $24 \mathrm{~h}$. After treatment, a fresh medium containing $10 \mu \mathrm{L} \mathrm{CCK}-8$ solution was added into each well of the plate and incubated for a further $1 \mathrm{~h}$. Then, CCK- 8 absorbance was read using a microplate reader at $450 \mathrm{~nm}$ (Tecan Trading AG, Zürich, Switzerland).

\subsubsection{Levels of MDA in HepG2 Cells}

To examine the protective effect of baicalein treatment on $\mathrm{CCl}_{4}$ induced cell death, HepG2 cells were pre-treated baicalein at 10 and $20 \mu \mathrm{M}$ for $2 \mathrm{~h}$, then treated with $0.4 \%$ $\mathrm{CCl}_{4}(v / v)$ for additional $24 \mathrm{~h}$. The levels of MDA were also measured in the cell samples as detailed above. 


\subsection{Statistical Analysis}

All data are expressed as mean \pm standard deviation (SD) unless specifically stated. All figures were drawn by using Graph Pad Prism 8.2 (Graph Pad Software, Inc. San Diego, CA, USA) and statistical differences were performed by using one-way analysis of variance from Graph Pad Prism 8.2. A Tukey's multiple comparisons test was used to compare any two means when the variance was homogeneous, otherwise, Dunnett's T3 test was used. A $p$ value $<0.05$ was considered as statistical significance.

\section{Results}

3.1. $\mathrm{CCl}_{4}$-Induced Acute Liver Damage Involves Upregulation of Genes Involved in Oxidative Stress, Inflammation, Apoptosis and Ferroptosis Pathways

The liver tissue gene expression levels at $24 \mathrm{~h}$ in mice exposed with $\mathrm{CCl}_{4}$ are shown in Supplementary Figure S1. Notably, the mRNA expression of genes enriched in the Nrf2 pathway (Nrf2 and HO-1 mRNAs increased to 1.73- and 4.68-fold, respectively), apoptosis (Bax, GADD45a, MAPK7, and $p 21$ mRNAs increased to 3.09-, 3.56-, 3.32-, 3.12fold, respectively), inflammation (NF- $\kappa B, T N F-a, I L 1 \beta, I L-6$, and $i N O S$ mRNAs increased to 4.60-, 6.50-, 7.54-, 5.32-, and 4.53-fold, respectively) and ferroptosis pathways (GPX1, GPX4, ALOX12, SCD1, and COX-2 mRNAs increased to 2.83-,3.55-, 3.45-, 3.19-, and 4.27fold, respectively) were significantly up-regulated, compared to that in the control group. Furthermore, we also identified from the Western protein expression results that, at $24 \mathrm{~h}$, $\mathrm{CCl}_{4}$ exposure significantly unregulated the levels of Nrf2, $\mathrm{HO}-1, \mathrm{ALOX} 12, \mathrm{COX}-2$ and $p 21$ protein expression, compared to that in the control groups (Figure 2A,B).
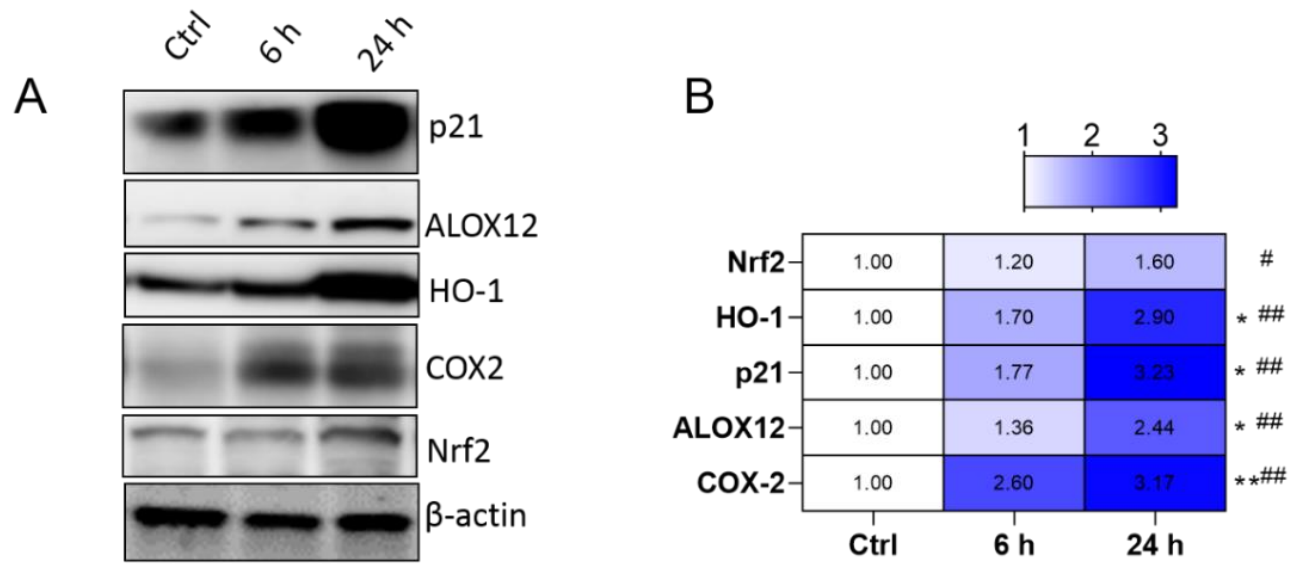

Figure 2. Protein expression levels involved ferroptosis were detected in the liver tissues of mice challenged with $\mathrm{CCl}_{4}$. (A) Protein expression levels of ALOX12, HO-1, COX-2, p21 and Nrf2 at 6 and $24 \mathrm{~h}$ identified by Western blotting analysis of liver tissues of mice treated with $\mathrm{CCl}_{4}$; the quantitative analysis is showed in $(\mathbf{B})(n=4) .6 \mathrm{~h} \mathrm{vs.} \operatorname{ctrl}^{*} p<0.05,{ }^{* *} p<0.01$; 24 h vs. ctrl, ${ }^{\#} p<0.05,{ }^{\# \#} p<0.01$. Ctrl: control.

\subsection{Baicalein and Fer-1 Supplementation Ameliorates $\mathrm{CCl}_{4}$-Induced Acute Liver Injury}

The hepatoprotective effects of baicalein and Fer-1 supplementation on $\mathrm{CCl}_{4}$-induced acute liver injury in mice were accessed through the measurement of AST and ALT serum levels and histopathological examination of liver sections (Figure 3). As shown in Figure 3A-D, $\mathrm{CCl}_{4}$ exposure significantly increased the serum AST and ALT activities (both $p<0.01$ ) compared to the untreated control group. Baicalein supplementation at doses of 25 and $100 \mathrm{mg} / \mathrm{kg} /$ day for 7 days (i.e., $\mathrm{CCl}_{4}+\mathrm{Bai} 25$ and $\mathrm{CCl}_{4}+$ Bai 100 groups) or Fer- 1 administration at $10 \mathrm{mg} / \mathrm{kg}$ markedly decreased the levels of serum AST and ALT (Figure 3A-D), compared to the $\mathrm{CCl}_{4}$-only group. Consistently, marked histopathological liver injury (SQS increased to 3.5) was detected at $24 \mathrm{~h}$ after $\mathrm{CCl}_{4}$ exposure, wherein large areas of cellular necrosis and numbers inflammatory cell infiltration were detected (Figure $3 \mathrm{E}, \mathrm{F}$ ). Baicalein or Fer-1 supplementation also significantly improved $\mathrm{CCl}_{4}$ induced 
pathology damage; the histological scores significantly decreased to $2.0(p<0.05), 1.5$ $(p<0.01)$ and $1.5(p<0.01)$ in the CCl4 + Bai $25, \mathrm{CCl}_{4}+$ Bai 100 groups, or $\mathrm{CCl}_{4}+$ Fer-1 groups, respectively (Figure 3E,F).

A

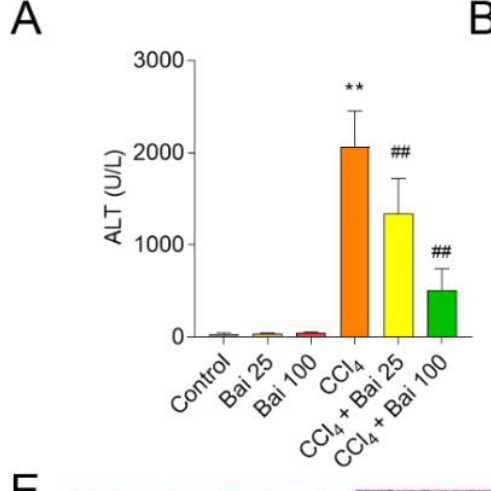

B

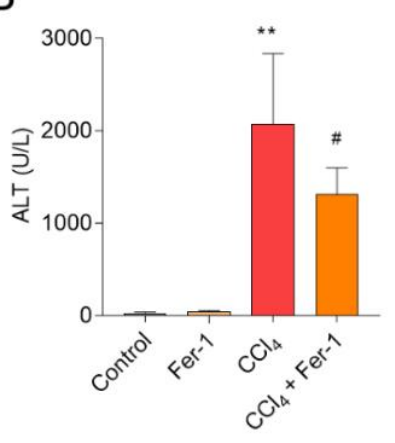

C



$\mathrm{D}$



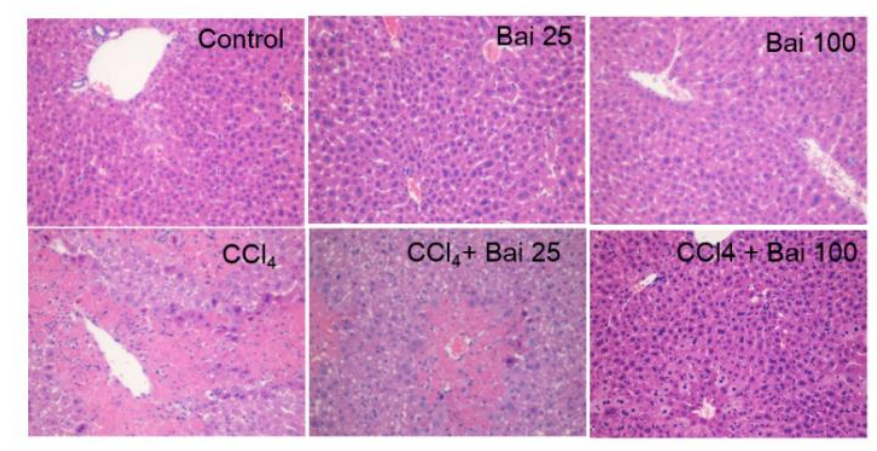

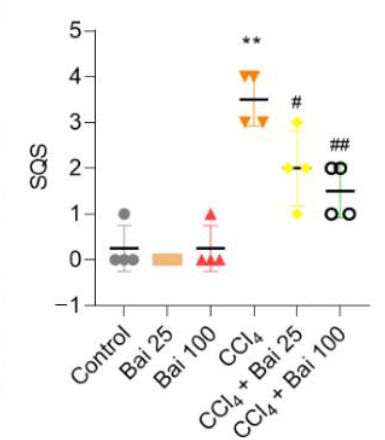

$\mathrm{F}$
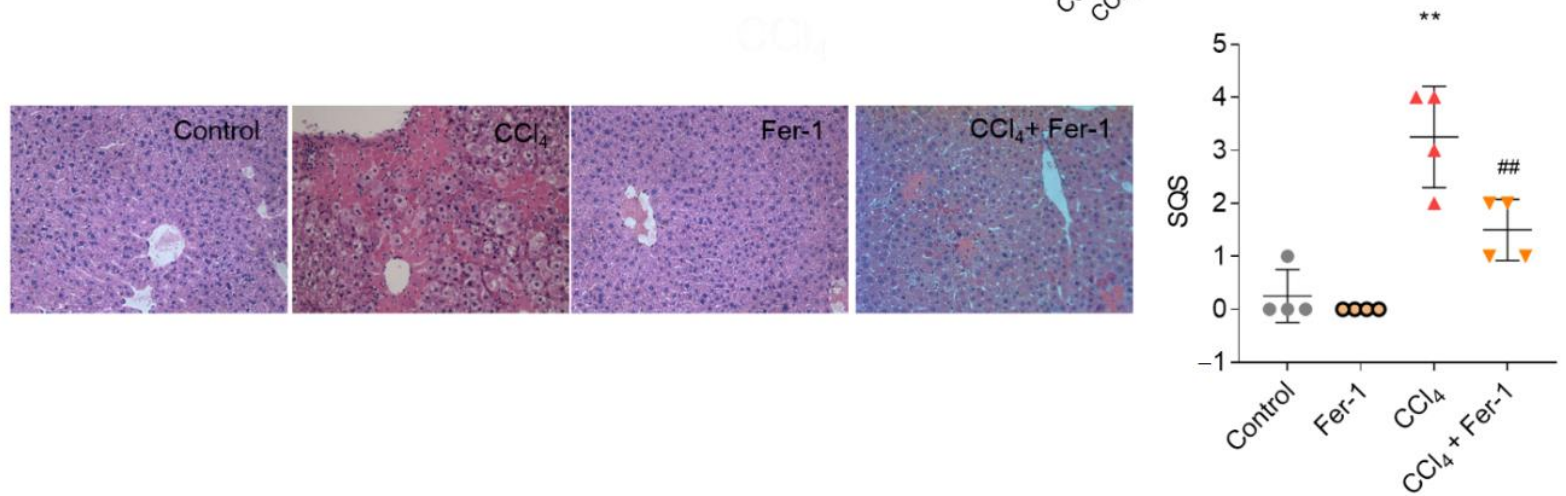

Figure 3. Effects of baicalein and Fer-1 supplementation on $\mathrm{CCl}_{4}$-induced liver dysfunction and histopathology. Levels of serum $(\mathbf{A}, \mathbf{B})$ ALT and $(\mathbf{C}, \mathbf{D})$ AST $(n=6)$. (E,F) Representative histopathological images of hematoxylin and eosin $(\mathrm{H} \& \mathrm{E})$ stained liver sections and their semi-quantitative scoring ( $\operatorname{SQS}(n=4))$. Magnification, $\times 20$. All results are presented as mean \pm SD. ${ }^{* *} p<0.01$, compared to the untreated control group, respectively; ${ }^{\#} p<0.05$ or ${ }^{\# \#} p<0.01$ compared to the $\mathrm{CCl}_{4}$ only group. Bai, baicalein. Fer-1, ferrostatin-1.

\subsection{Baicalein and Fer-1 Supplementation Ameliorates $\mathrm{CCl}_{4}$-Induced Ferroptosis}

Baicalein supplementation markedly inhibited the expression of markers of ferroptosis including SCD-1, ALOX12 and COX-2 mRNAs in the liver tissues of mice, compared to that in the $\mathrm{CCl}_{4}$ only group (Figure $4 \mathrm{~A}$ ). Baicalein supplementation also significantly improved $\mathrm{CCl}_{4}$-induced lipid peroxidation $\left(\mathrm{CCl}_{4}\right.$ only group $\mathrm{MDA}=2.69 \mathrm{mmol} / \mathrm{mg} ; \mathrm{CCl}_{4}+\mathrm{Bai}$ $25 \mathrm{MDA}=2.27 \mathrm{mmol} / \mathrm{mg} ; \mathrm{CCl}_{4}+$ Bai $100 \mathrm{MDA}=2.07 \mathrm{mmol} / \mathrm{mg}$; both $\left.p<0.01\right)$ and recovered GSH levels (Figure 4B,C). The MDA levels $(p<0.01)$ and the expressions of COX2 mRNA were also reduced following Fer- 1 administration, compared to the $\mathrm{CCl}_{4}$-only group (Figure 4D,E). 
$\mathrm{A} \square \mathrm{Ctrl}$
$\mathrm{CCl}_{4} \square \mathrm{Bai}_{2} 5 \square$ Bai 100
$\mathrm{CCl}_{4}+$ Bai $25 \square \mathrm{CCl}_{4}+$ Bai 100

B

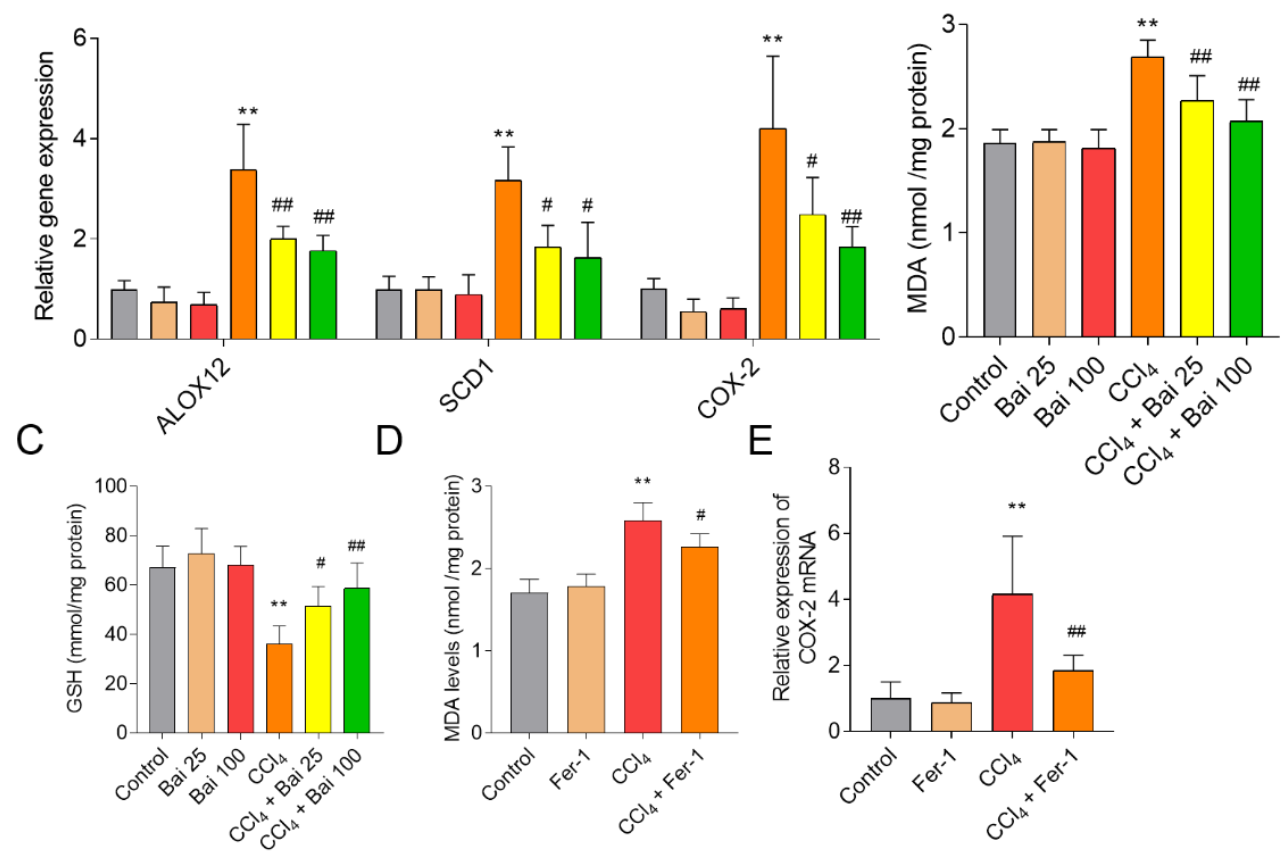

Figure 4. Effects of baicalein and Fer-1 supplementation on the expression of COX-2, lipid peroxidation and GSH in the liver tissues of mice challenged with $\mathrm{CCl}_{4}$. (A) Effect of baicalein supplementation on expression of ALOX12, SCD1, and COX-2 mRNAs in liver tissues. (B) Effect of baicalein supplementation on the levels of MDA in liver tissues. (C) Effect of baicalein supplementation on the levels of reduced GSH (shown as GSH) in liver tissues. (D) Effect of Fer-1 supplementation on the levels of MDA in liver tissues. (E) Effect of Fer-1 supplementation on the expression of COX-2 mRNA in liver tissues. All data are presented as mean $\pm \mathrm{SD}(n=6) .{ }^{* *} p<0.01$, compared to the untreated control group, respectively; ${ }^{\#} p<0.05$ or $\#$ \# $p 0.01$ compared to the $\mathrm{CCl}_{4}$-only group. MDA: malondialdehyde; GSH: glutathione; Bai: baicalein.

\subsection{Baicalein Supplementation Activates Liver Antioxidant Defense Pathways}

As shown in Figure 5, at $24 \mathrm{~h}, \mathrm{CCl}_{4}$ exposure per se up-regulated the expression of $\mathrm{Nrf2}$ and HO-1 mRNAs compared to that in the control group (1.6- and 2.0-fold, respectively; both $p<0.01$ ) (Figure 5A,B). Baicalein supplementation, particularly at $100 \mathrm{mg} / \mathrm{kg} /$ day, further up-regulated the expressions of Nrf2 and HO-1 mRNAs (all $p<0.01$ ), compared to that in the $\mathrm{CCl}_{4}$ only group. Moreover, baicalein supplementation at the doses of 25 and $100 \mathrm{mg} / \mathrm{kg} /$ day for 7 consecutive days, significantly up-regulated the activities of antioxidant enzymes SOD and CAT in the liver tissues, compared to the $\mathrm{CCl}_{4}$-only group (Figure 5C,D). 
A


B
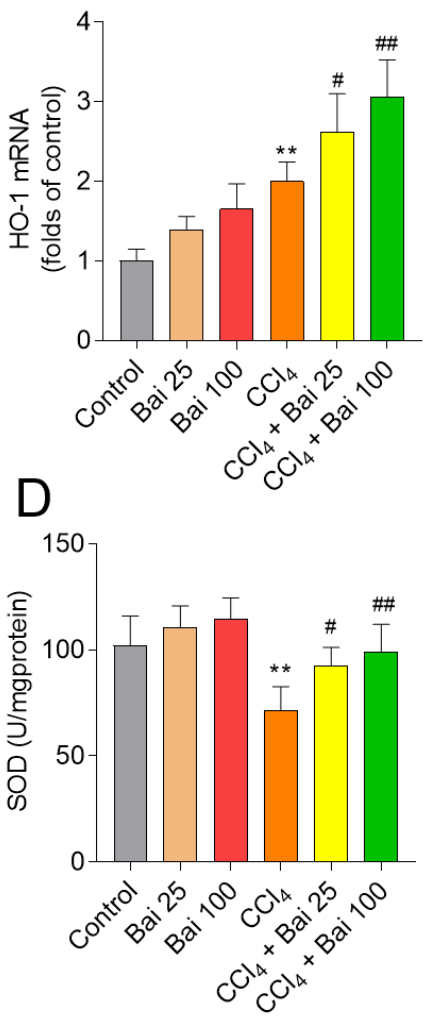

Figure 5. Effects of baicalein supplementation on the antioxidant defense pathways in liver tissues of mice challenged with $\mathrm{CCl}_{4}$. (A) Nrf2 mRNA; (B) HO-1 mRNA; (C) CAT activity; and (D) SOD activity. Data are presented as mean $\pm \operatorname{SD}(n=6) .{ }^{* *} p<0.01$, compared to the control group; ${ }^{\#} p<0.05$ or \#\# $p<0.01$ compared to the $\mathrm{CCl}_{4}$ model group. Bai: baicalein.

\subsection{Baicalein Supplementation Attenuates $\mathrm{CCl}_{4}$-Induced Caspase Activation and Apoptosis in the Liver Tissues}

TUNEL staining showed that baicalein supplemented mice displayed attenuated cellular apoptotic rates in their liver tissues (Figure 6A,B). Baicalein supplementation at the doses of 25 and $100 \mathrm{mg} / \mathrm{kg} /$ day for consecutive 7 days significantly decreased the activity of caspase-3 to 3.5- and 2.6- fold, respectively; and decreased the caspase- 9 to 2.0- and 1.6- fold, respectively (Figure 6C,D). In addition, baicalein supplementation at $100 \mathrm{mg} / \mathrm{kg} /$ day also inhibited the expression of Bax, GADD45a, and $p 21 \mathrm{mRNAs}$, all of which were significantly elevated following $\mathrm{CCl}_{4}$ exposure (Figure $6 \mathrm{E}$ ). There were no marked changes in the activities of caspase- 9 and -3 , the rate of cellular apoptosis and mRNA expression of Bax, GADD45a, and $p 21$ in the Bai 25 and Bai 100 groups, compared to the untreated control group. 


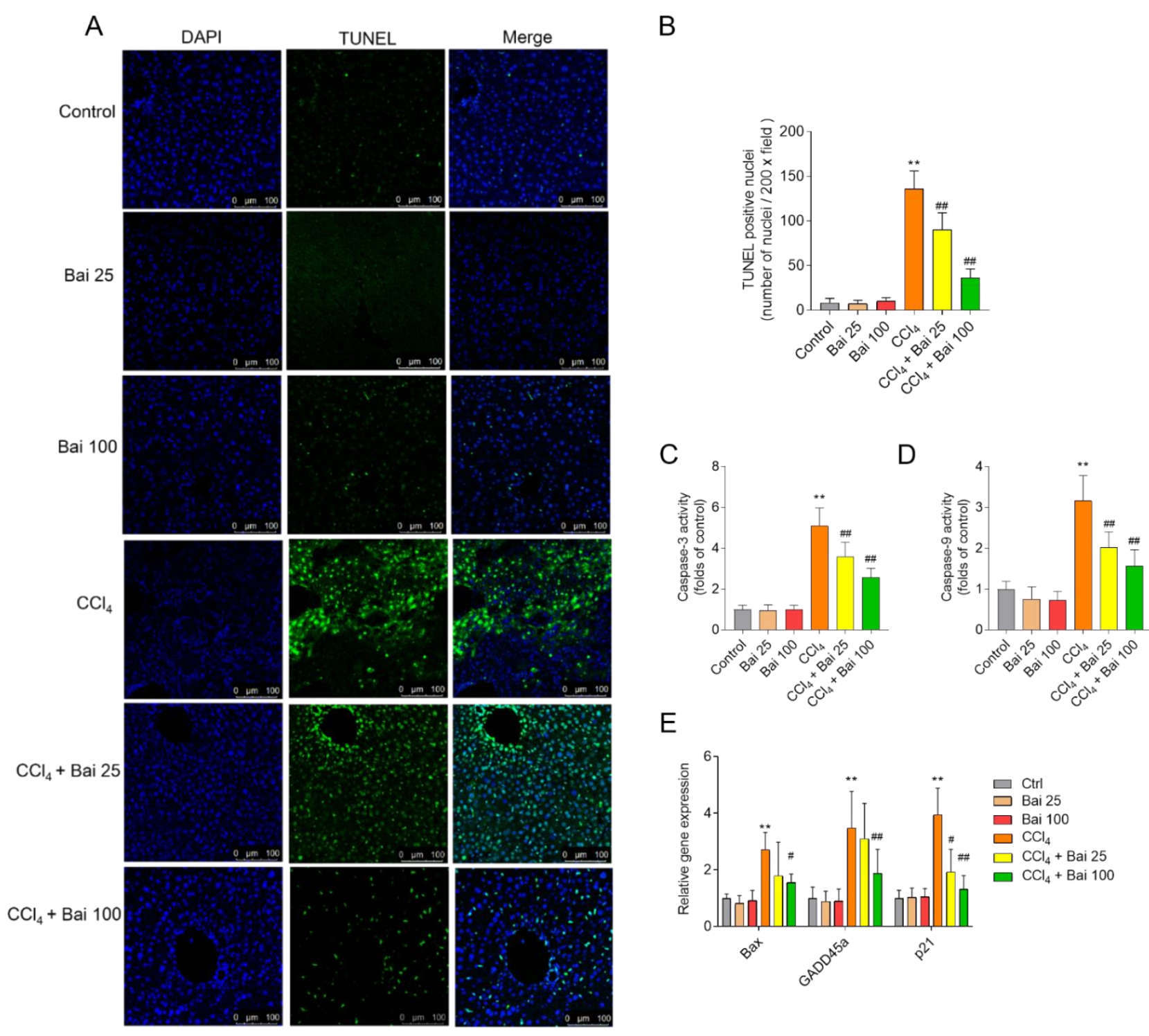

Figure 6. Effects of baicalein supplementation on apoptotic pathway in the liver tissues of mice challenged with $\mathrm{CCl}_{4}$. (A) Representative TUNEL-stained sections showing apoptosis in the liver tissue of mice. (B) Quantitative analysis of TUNEL positive rates $(n=4)$. (C,D) Activities of $(\mathbf{C})$ caspases-3 and -9 (D) $(n=6)$. (E) The relative expression of Bax, GADD45a and $p 21$ mRNAs in the liver tissues $(n=5) .{ }^{* *} p<0.01$, compared to the control group; ${ }^{\#} p<0.05$ or ${ }^{\# \#} p<0.01$, compared to the $\mathrm{CCl}_{4}$ only group. Bar $=100 \mu \mathrm{m}$. Bai: baicalein.

\subsection{Baicalein Supplementation Ameliorates the NF- $\kappa B$ Mediated Inflammatory Response}

The liver tissues of mice treated with $\mathrm{CCl}_{4}$ alone displayed significantly elevated levels of NF- $k B, I L-1 \beta, I L-6, T N F-\alpha$, and $i N O S$ mRNAs (Figure 7A), compared to untreated mice. Baicalein supplementation at the doses of 25 and $100 \mathrm{mg} / \mathrm{kg} /$ day markedly attenuated $\mathrm{CCl}_{4}$ exposure-induced the increases in the levels of $I L-1 \beta, I L-6$ and TNF- $\alpha$ in the liver tissues (Figure 7B-D). Baicalein supplementation also decreased $\mathrm{CCl}_{4}$ induced increases of $i N O S$ and NO in the liver tissues (Figure 7E,F, respectively). Baicalein supplementation at 25 and $100 \mathrm{mg} / \mathrm{kg} /$ day alone did not perturb the level of any of the aforementioned inflammatory markers. 


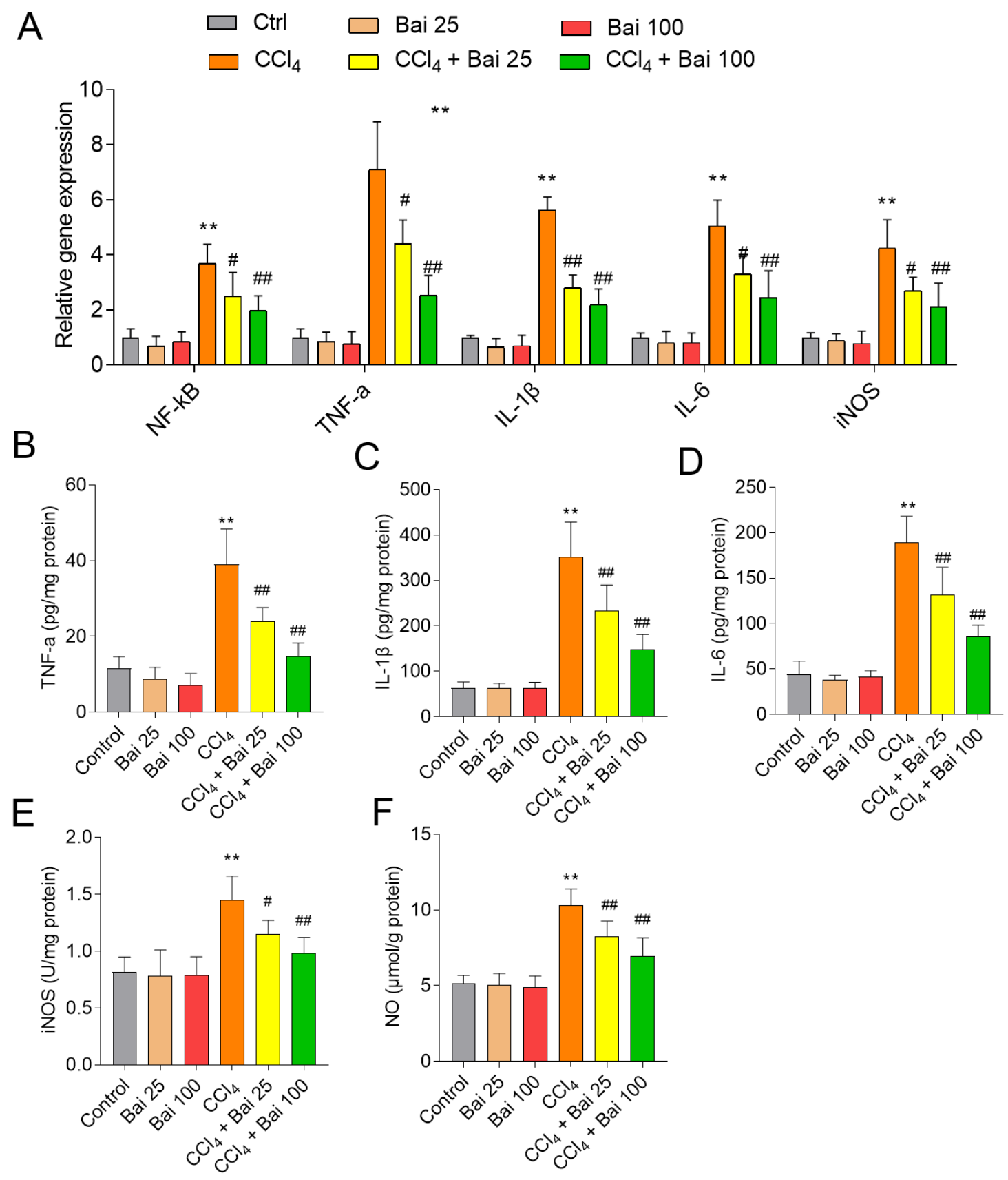

Figure 7. Effects of baicalein supplementation on $\mathrm{CCl}_{4}$-induced inflammation in the liver tissues of mice. (A) The relative expression levels of $N F-\kappa B, T N F-a, I L-1 \beta, I L-6$, and $i N O S$ mRNAs; (B) levels of $I L-1 \beta$ protein; (C) levels of $I L-6$ protein; (D) levels of TNF-a protein; (E) levels of $i N O S$ protein; (F) levels of NO. All data are presented as mean \pm SD $(n=6)$. ${ }^{* *} p<0.01$, compared to the control group; ${ }^{\#} p<0.05$ or ${ }^{\# \#} p<0.01$, compared to the $\mathrm{CCl}_{4}$ only group. Bai: baicalein.

\subsection{Baicalein Attenuates $\mathrm{CCl}_{4}$-Induced Cell Death in HepG2 Cells}

As shown in Figure $8 \mathrm{~A}, \mathrm{CCl}_{4}$ exposure for $24 \mathrm{~h}$ significantly unregulated the expression of ALOX12, Nrf2 and HO-1 mRNAs in HepG2 cells. Baicalein supplementation at $10 \mu \mathrm{M}$ and 20 significantly inhibited $\mathrm{CCl}_{4}$ - or erastin-induced cell death (Supplementary Figure S2) and significantly inhibited the increase in MDA levels in HepG2 cells (Figure 8B). Knockdown of ALOX12 and Nrf2 genes by SiRNAs were confirmed by monitoring mRNA and protein expression (Supplementary Figure S3). Knockdown of ALOX12 gene significantly inhibited erastin- or $\mathrm{CCl}_{4}$-induced cell death in HepG2 cells (Figure 8C and Supplementary Figure $\mathrm{S} 4 \mathrm{~A})$ and abolished the protective effect of baicalein. In contrast, knockdown of Nrf2 gene 
significantly promoted erastin- or $\mathrm{CCl}_{4}$-induced cell death and partly abolished the protective effect of baicalein (Figure 8D and Supplementary Figure S4B).

A

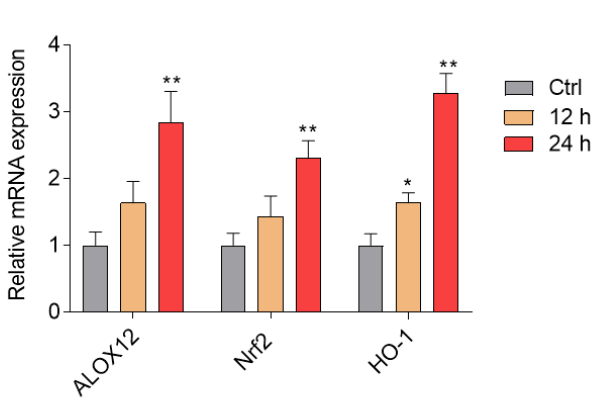

C

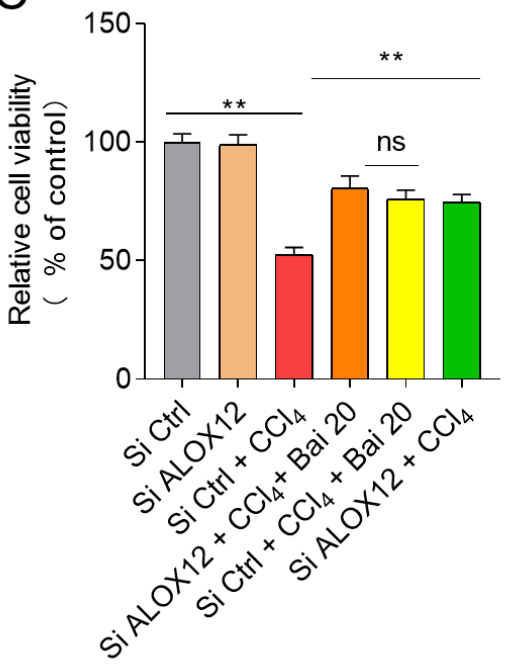

B

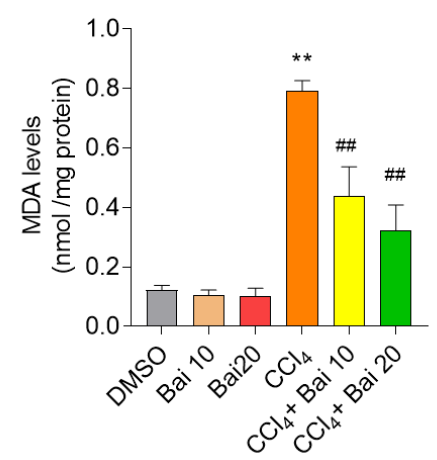

D

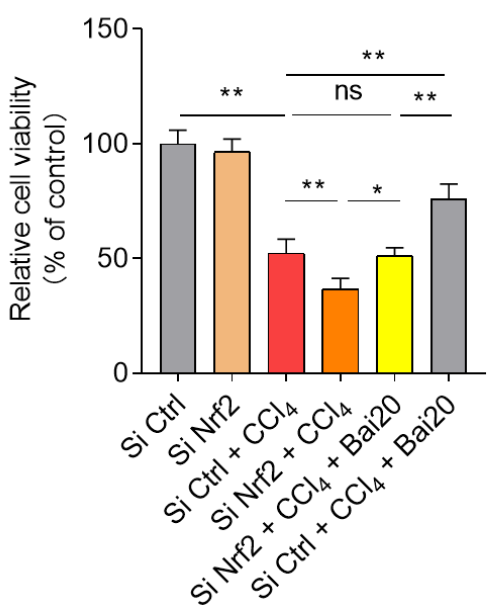

Figure 8. Effect of $A L O X 12$ and $N r f 2$ genes knockdown on the protective effect of baicalein in HepG2 cells. (A) The expression of ALOX12, Nrf2, and HO-1 mRNAs were examined after $0.4 \% \mathrm{CCl}_{4}$ treatment for $12 \mathrm{~h}$ and $24 \mathrm{~h}$ in HepG2 cells. Data are presented as mean $\pm \mathrm{SD}(n=3) .{ }^{*} p<0.05$, ** $p<0.01$, compared to the control group. (B) Effect of baicalein supplementation on levels of MDA in HepG2 cells. Knockdown of ALOX12 (C) or Nrf2 (D) on the protective effect of baicalein on $\mathrm{CCl}_{4}$ $(0.4 \%)$ treatment (for $24 \mathrm{~h}$ ) -induced cell death. SiRNA\#1s targeting ALOX12 and Nrf2 gene were used here, respectively. All data are presented as mean $\pm \mathrm{SD}(n=3) .{ }^{*} p<0.05,{ }^{* *} p<0.01$, compared to the $\mathrm{SiCtrl}$ group. ${ }^{\#} p<0.01$, compared to the $\mathrm{CCl}_{4}$ alone group. Ctrl: control. ns: no significance.

\section{Discussion}

Liver disease is a global public health burden that causes one million deaths annually [1]. Currently available hepato-protective drugs are limited in efficacy or elicit many adverse reactions [33]. These factors highlight the urgent need for novel hepatoprotective agents with low or no adverse effects. Natural products have been humankind's most fruitful source of drugs [34]. In line with previous reports, the present study showed that $\mathrm{CCl}_{4}$ exposure significantly up-regulated AST and ALT levels [35]. Histological assessment of the liver tissues of mice treated with $\mathrm{CCl}_{4}$ per se revealed hepatotoxicosis seen as fragmented, condensed and lost nuclei. Supplementation with baicalein markedly attenuated $\mathrm{CCl}_{4}$-induced acute liver injury in mice via the inhibition of oxidative stress, ferroptosis, caspase activation, apoptosis, and NF-KB-mediated inflammation (Figures 2-7).

It is well known that $\mathrm{CCl}_{4}$ induced hepatoxicity partly depends on the production of excessive ROS, which in turn causes damage to cellular lipids, DNA, and proteins [13-15]. Lipid peroxidation is one of the principal hallmarks of $\mathrm{CCl}_{4}$-induced liver injury [36]. 
Lipid peroxides react with metals such as iron, resulting in many reactive carbonyls (e.g., 4-hydroxynonenal and MDA). These reactive carbonyls become strongly conjugated to GSH and in turn deplete cellular GSH levels. In the current study, we detected markedly depleted GSH levels, increased MDA (a biomarker of lipid peroxidation) in the liver tissues of mice at $24 \mathrm{~h}$ post $\mathrm{CCl}_{4}$ exposure [37], which were all markedly improved by baicalein supplementation. The anti-oxidant properties of baicalein have been associated with its ability to ameliorate cisplatin, colistin and hypoxia-reoxygenation-induced nephrotoxicity and doxorubicin-induced cardiotoxicity in mice $[23,28,38,39]$. The strong anti-oxidant property of baicalein is conferred by its three 5,6,7 position $\mathrm{OH}$-groups that play a critical role in scavenging ROS $[26,40]$. In the present study, baicalein supplementation markedly inhibited $\mathrm{CCl}_{4}$-induced increases in the levels of $\mathrm{NO}$ and $i \mathrm{NOS}$ activities (Figure 7), two biomarkers of nitrative stress [41]. NO can react with superoxide leading to formation of highly reactive peroxynitrite, causing DNA damage and apoptotic cell death [42,43]. Collectively, our findings indicate that baicalein can protective $\mathrm{CCl}_{4}$-induced acute liver injury by inhibiting nitrative stress.

Recently, Choi et al., reported that baicalein is an activator of nuclear factor-erythroid 2-related factor 2 ( Nrf2), a critical redox-sensitive transcription factor in the cellular antioxidant response [44-48]. The activation of Nrf2 could attenuate cellular oxidative damage by activating genes that encode phase II detoxifying enzymes and antioxidant enzymes, such as CAT, SOD, and HO-1 [41]. $\mathrm{CCl}_{4}$ exposure is known to cripple the Nrf2 antioxidant defense system and exacerbate oxidative damage in the liver [14,36]. Consistently, we found that $\mathrm{CCl}_{4}$ exposure significantly decreased the activities of $S O D$ and $C A T$ in the liver tissues of mice, whereas baicalein supplementation markedly up-regulated the activities of $S O D$ and CAT; and activated Nrf2 expression and its downstream gene HO-1. Silencing $N r f 2$ at the genetic level has been shown to diminish the protective effect of baicalein on $\mathrm{H}_{2} \mathrm{O}_{2}$-induced oxidative damage in HEI193 Schwann and NG108-15 cells [47-49]. Similarly, baicalein supplementation has been shown to markedly improve colistin-induced nephrotoxicity in mice via the activation of Nrf2/HO-1 pathway and inhibition of NF$\kappa B$ mediated inflammatory response [28]. Coincidently, knockdown of Nrf2 inhibited erastin-induced ferroptotic cell death in human HepG2 cells (Figure 8), indicating that $\mathrm{Nrf2}$ potentially plays an important role in ferroptosis [50]. In the present study, $\mathrm{CCl}_{4}$ exposure significantly increased the expression of Nrf2 mRNA and protein levels and the expression of its downstream gene $\mathrm{HO}-1$ in the liver tissues of mice (Figure 5). Baicaien supplementation counteracted these negative perturbations and significantly unregulated the expression of Nrf2 and HO-1 mRNA in the liver tissues (Figure 5). Consistently, knockdown of $\mathrm{Nrf2}$ by RNAi silencing promoted $\mathrm{CCl}_{4}$-induced cell death in HepG2 cells and partly abolished the protective effect of baicalein (Figure 8). Taken together, our results suggested that baicalein protects against $\mathrm{CCl}_{4}$ induced acute liver injury via activation of the Nrf2/HO-1 anti-oxidant pathway.

Our present results showed that baicalein supplementation markedly attenuated $\mathrm{CCl}_{4}$ -induced activation of caspases-9 and -3 and cellular apoptosis; and inhibited p21, GADD45a and Bax expression (Figure 6). Caspase-9 is an important biomarker in mitochondrialdependent apoptosis [45]. Mitochondria are particularly susceptible to ROS [51]; coincidently, $\mathrm{CCl}_{4}$ exposure has been associated with marked mitochondrial dysfunction, resulting in cytochrome $\mathrm{C}$ release which triggers the mitochondrial apoptotic death pathway $[15,52]$. In previous studies, baicalein supplementation was shown to markedly inhibit colistin-induced activation of caspases-9 and -3 in the kidney tissues of mice or inhibit $\mathrm{CCl}_{4}$ exposure-induced mitochondrial apoptotic cell death in liver tissues of mice $[28,53]$. Similarly, Jeong and colleagues reported that baicalein treatment $(100 \mu \mathrm{M})$ markedly inhibited $\mathrm{H}_{2} \mathrm{O}_{2}$-induced oxidative stress, caspases activation, and apoptosis in HEI193 Schwann cells [54]. Taken together, our results indicated that baicalein supplementation ameliorates toxin-induced oxidative stress in the liver, thereby preventing mitochondrial dysfunction and apoptotic cell death. 
The inflammatory response is one of the main events associated with the pathological progress of $\mathrm{CCl}_{4}$-induced acute liver injury [4-6,10,12,55-58]. NF- $\mathrm{KB}$ is a critical transcriptional mediator of pro-inflammatory cytokine expression, such as IL-1 $\beta$, IL-6, TNF- $\alpha$, and COX-2 [59]. It has been reported that baicalein treatment of macrophages down-regulated lipopolysaccharide-induced production of TNF- $\alpha$, IL-6 and iNOS [60]. Wu et al. demonstrated that oral administration of baicalein can improve D-galactosamine or lipopolysaccharide or $\mathrm{CCl}_{4}$-induced acute liver failure and liver fibrosis by blocking the recruitment of $N F-\kappa B$ signaling $[42,61,62]$. Consistently, our results showed that baicalein supplementation markedly inhibited the production of IL-1 $\beta$, TNF- $\alpha$, and IL-6 levels, and the expression of $N F-\kappa B$ mRNA in the liver tissues of mice exposed to $\mathrm{CCl}_{4}$ (Figure 7). Notably, Nrf2 activation can lead to the inhibition of oxidative stress driven by NF- $\kappa B$ nuclear translocation mediated inflammatory response via $\mathrm{HO}-1$ end-products (i.e., bilirubin) [59]. Therefore, the activation of Nrf2/HO-1 pathway caused by baicalein may partly contribute to the inhibition of NF-kB-mediated inflammatory response, nonetheless, the precise molecular mechanism requires further investigation.

Ferroptosis is a type of regulated cell death characterized by iron-dependent accumulation of lipid hydroperoxides [18,30]. Ferroptosis is triggered when intracellular glutathione peroxidase 4 (GPX4) is inhibited directly; or indirectly by a decrease in cellular GSH levels $[18,30]$. $\mathrm{CCl}_{4}$-induced acute liver damage displays some hall mark features of ferroptosis, including increased lipid peroxidation and expression of COX-2, p53, SAT1 and GSH depletion [63,64]; and is inhibited by prior- or co-administration of the ferroptosis inhibitors desferrioxamine, GSH, or NAC [19-21]. A recent study demonstrated that ferroptosis participated in acetaminophen-induced acute liver injury in a mouse model [31]. A high-throughput natural product library screen for ferroptosis inhibitors identified baicalein as a potential hit [65]. COX-2 is considered as a biomarker of ferroptotic cell death in murine models of acute liver injury, acute renal failure and cardiomyopathy $[31,66,67]$. In the present study, we showed that baicalein significantly ameliorated $\mathrm{CCl}_{4}$-induced lipid peroxidation, GSH depletion and COX-2 mRNA expression. Similarly, Fer-1, an inhibitor of ferroptosis, also significantly inhibited $\mathrm{CCl}_{4}$-induced acute liver injury. Fer-1 also significantly inhibited the expression of $C O X-2$ mRNA and the levels of MDA in the liver tissue of mice. In addition, baicalein supplementation inhibited ferroptosis in HepG2 cells following erastin treatment. Taken together, these findings suggest that baicalein supplementation can inhibit $\mathrm{CCl}_{4}$-induced ferroptosis that partly contributes to its protective effect on $\mathrm{CCl}_{4}$-induced acute liver injury in mice.

Baicalein is a known inhibitor of 12/15-lipoxygenases (12/15-LOXs), two seminal enzymes involved in the metabolism of polyunsaturated fatty acids [68]. In the present study, we demonstrated that $\mathrm{CCl}_{4}$ exposure increased the expression of stearoyl-CoA desaturase-1 (SCD1) and ALOX12, which are the positive re-enforcers in the process of ferroptotic cell death [69]. Baiclaein has been shown to inhibit ischemia-reperfusion-induced cardiac damage in rats via the inhibition of $A L O X 12$ activity [70] wherein ferroptosis is an underlying mechanism [67]. In the current study, baicalein supplementation markedly inhibited the expression of $S C D 1$ and ALOX12 in the liver tissues of mice. Furthermore, our present study showed that knockdown of $A L O X 12$ significantly inhibited ferroptosis following erastin- and $\mathrm{CCl}_{4}$-induced HepG2 cell death. Furthermore, silencing ALOX12 significantly abolished the protective effect of baicalein (Figure 8 ). This would suggest that baicalein mediated inhibition of $\mathrm{CCl}_{4}$-induced ferroptosis is partly dependent on the inhibition of ALOX12 activity. Previous studies also showed that inhibition of ALOX12 gene expression also contributed to inhibition of inflammatory response [71]. Whether the inhibition of $A L O X 12$ gene expression contributes significantly to the inhibitory effect of baicalein on $\mathrm{CCl}_{4}$-induced inflammatory still requires further investigation.

In humans, a recent Phase I trial showed that oral baicalein at 100-2800 mg daily (it was equal to about $1.7-46.7 \mathrm{mg} / \mathrm{kg}$ per day, standard weight of human was set as $60 \mathrm{~kg}$ ) displays favorable pharmacokinetic profiles, and the doses are safe and well tolerated [72]. Similarly, in another human clinical trial, oral baicalein at 0,400 , and $800 \mathrm{mg}$ (it was equal to 
about 6.7 and $13.3 \mathrm{mg} / \mathrm{kg}$, respectively) (once daily at days 1 and 10 and twice daily on days 3-9) for 10 days in healthy Chinese volunteers showed good safety and tolerability [73]. Therefore, baicalein at $100 \mathrm{mg} / \mathrm{kg} /$ day (it was equal to about $10 \mathrm{mg} / \mathrm{kg} /$ day in human according to conversion of human and mouse body surface) at the present study may be suitable to use in humans as a hepatoprotective agent against acute liver injury. Further clinical trials are still required.

\section{Conclusions}

In conclusion, our results reveal that $\mathrm{CCl}_{4}$-induced acute liver injury involved multiple cellular process, including apoptosis, oxidative stress, inflammation, and ferroptosis. Baicalein supplementation ameliorates $\mathrm{CCl}_{4}$-induced acute liver injury in mice by upregulating the antioxidant defense functions and downregulating oxidative stress, apoptosis, inflammation and ferrroptosis, which may involve the activation of Nrf2 pathway and the inhibition of ALOX12 and NF- $\mathrm{kB}$ pathways. The current study highlights the potential clinical utility of baicalein supplementation for patients suffering from acute liver disease and paves the way for future clinical trials.

Supplementary Materials: The following are available online at https://www.mdpi.com/article/ 10.3390/antiox10060976/s1, Figure S1: Gene expression involved apoptosis, inflammation and ferroptosis pathway in the liver tissues exposed with $\mathrm{CCl}_{4}$. Figure S2: Gene and protein expression was detected in HepG2 cells with the knockdown of ALOX12 and Nrf2 genes. Figure S3: Effect of baicalein on erastin and $\mathrm{CCl}_{4}$-induced cell death in $\mathrm{HepG} 2$ cells. Figure S4: Effect of knockdown of ALOX12 and Nrf2 on $\mathrm{CCl}_{4}$-induced cell death in HepG2 cells. Table S1: Primers for qRT-PCR.

Author Contributions: Conceptualization, C.D.; methodology, C.D. and Y.W.; software, H.L.; validation, C.D. and Y.W.; formal analysis, S.T.; investigation, C.D.; data curation, C.D.; writing-original draft preparation, C.D.; writing-review and editing, C.D., J.S. and T.V.; project administration, C.D.; funding acquisition, S.T. and H.L. All authors have read and agreed to the published version of the manuscript.

Funding: This research was funded by the National Key Research and Development Program of China (2017YFC1600305) and Major Science and Technology Innovation Project of Shandong Province (2019JZZY010735).

Institutional Review Board Statement: The study was conducted according to the guidelines of Institutional Animal Care and Use Committee at the China Agricultural University (Approval number CAU20190902-2).

Informed Consent Statement: Not applicable.

Data Availability Statement: All data in the present study are available on request from corresponding author.

Conflicts of Interest: The authors declare no conflict of interest.

\section{References}

1. Xiao, J.; Wang, F.; Wong, N.K.; He, J.; Zhang, R.; Sun, R.; Xu, Y.; Liu, Y.; Li, W.; Koike, K.; et al. Global liver disease burdens and research trends: Analysis from a chinese perspective. J. Hepatol. 2019, 71, 212-221. [CrossRef] [PubMed]

2. Singh, D.; Cho, W.C.; Upadhyay, G. Drug-induced liver toxicity and prevention by herbal antioxidants: An overview. Front. Physiol. 2015, 6, 363. [CrossRef] [PubMed]

3. Wu, Z.; Han, M.; Chen, T.; Yan, W.; Ning, Q. Acute liver failure: Mechanisms of immune-mediated liver injury. Liver Int. 2010, 30, 782-794. [CrossRef] [PubMed]

4. Niu, L.; Cui, X.; Qi, Y.; Xie, D.; Wu, Q.; Chen, X.; Ge, J.; Liu, Z. Involvement of tgf-beta1/smad3 signaling in carbon tetrachlorideinduced acute liver injury in mice. PLoS ONE 2016, 11, e0156090. [CrossRef] [PubMed]

5. Cong, M.; Zhao, W.; Liu, T.; Wang, P.; Fan, X.; Zhai, Q.; Bao, X.; Zhang, D.; You, H.; Kisseleva, T.; et al. Protective effect of human serum amyloid $\mathrm{p}$ on ccl4-induced acute liver injury in mice. Int. J. Mol. Med. 2017, 40, 454-464. [CrossRef]

6. Zhang, D.G.; Zhang, C.; Wang, J.X.; Wang, B.W.; Wang, H.; Zhang, Z.H.; Chen, Y.H.; Lu, Y.; Tao, L.; Wang, J.Q.; et al. Obeticholic acid protects against carbon tetrachloride-induced acute liver injury and inflammation. Toxicol. Appl. Pharmacol. 2017, 314, 39-47. [CrossRef] [PubMed] 
7. Xiao, J.; Liong, E.C.; Huang, H.; On Tse, W.; Lau, K.S.; Pan, J.; Nanji, A.A.; Fung, M.L.; Xing, F.; Tipoe, G.L. Cyclooxygenase-1 serves a vital hepato-protective function in chemically induced acute liver injury. Toxicol. Sci. 2015, 143, 430-440. [CrossRef]

8. Lee, J.; Giordano, S.; Zhang, J. Autophagy, mitochondria and oxidative stress: Cross-talk and redox signalling. Biochem. J. 2012, 441, 523-540. [CrossRef] [PubMed]

9. Ding, J.; Cui, X.; Liu, Q. Emerging role of hmgb1 in lung diseases: Friend or foe. J. Cell. Mol. Med. 2017, 21, 1046-1057. [CrossRef] [PubMed]

10. Zou, Y.; Xiong, J.B.; Ma, K.; Wang, A.Z.; Qian, K.J. Rac2 deficiency attenuates ccl4-induced liver injury through suppressing inflammation and oxidative stress. Biomed. Pharmacother. 2017, 94, 140-149. [CrossRef]

11. Zeng, B.; Su, M.; Chen, Q.; Chang, Q.; Wang, W.; Li, H. Protective effect of a polysaccharide from anoectochilus roxburghii against carbon tetrachloride-induced acute liver injury in mice. J. Ethnopharmacol. 2017, 200, 124-135. [CrossRef] [PubMed]

12. Torres, L.R.; Santana, F.C.; Torres-Leal, F.L.; Melo, I.L.; Yoshime, L.T.; Matos-Neto, E.M.; Seelaender, M.C.; Araujo, C.M.; Cogliati, B.; Mancini-Filho, J. Pequi (caryocar brasiliense camb.) almond oil attenuates carbon tetrachloride-induced acute hepatic injury in rats: Antioxidant and anti-inflammatory effects. Food Chem. Toxicol. 2016, 97, 205-216. [CrossRef] [PubMed]

13. Wang, M.; Niu, J.; Ou, L.; Deng, B.; Wang, Y.; Li, S. Zerumbone protects against carbon tetrachloride (ccl4)-induced acute liver injury in mice via inhibiting oxidative stress and the inflammatory response: Involving the tlr4/nf-kappab/cox-2 pathway. Molecules 2019, 24, 1964. [CrossRef] [PubMed]

14. Peng, X.; Dai, C.; Liu, Q.; Li, J.; Qiu, J. Curcumin attenuates on carbon tetrachloride-induced acute liver injury in mice via modulation of the nrf2/ho-1 and tgf-beta1/smad3 pathway. Molecules 2018, 23, 215. [CrossRef] [PubMed]

15. Dai, C.; Xiao, X.; Li, D.; Tun, S.; Wang, Y.; Velkov, T.; Tang, S. Chloroquine ameliorates carbon tetrachloride-induced acute liver injury in mice via the concomitant inhibition of inflammation and induction of apoptosis. Cell Death Dis. 2018, 9, 1164. [CrossRef] [PubMed]

16. Domitrovic, R.; Jakovac, H.; Blagojevic, G. Hepatoprotective activity of berberine is mediated by inhibition of tnf-alpha, cox-2, and inos expression in ccl(4)-intoxicated mice. Toxicology 2011, 280, 33-43. [CrossRef]

17. Wang, W.; Wang, S.; Liu, J.; Cai, E.; Zhu, H.; He, Z.; Gao, Y.; Li, P.; Zhao, Y. Sesquiterpenoids from the root of panax ginseng protect ccl4-induced acute liver injury by anti-inflammatory and anti-oxidative capabilities in mice. Biomed. Pharmacother. 2018, 102, 412-419. [CrossRef]

18. Stockwell, B.R.; Friedmann Angeli, J.P.; Bayir, H.; Bush, A.I.; Conrad, M.; Dixon, S.J.; Fulda, S.; Gascon, S.; Hatzios, S.K.; Kagan, V.E.; et al. Ferroptosis: A regulated cell death nexus linking metabolism, redox biology, and disease. Cell 2017, 171, 273-285. [CrossRef]

19. Leu, J.I.; Murphy, M.E.; George, D.L. Mechanistic basis for impaired ferroptosis in cells expressing the african-centric s47 variant of p53. Proc. Natl. Acad. Sci. USA 2019, 116, 8390-8396. [CrossRef]

20. Cai, Z.; Lou, Q.; Wang, F.; Li, E.; Sun, J.; Fang, H.; Xi, J.; Ju, L. N-acetylcysteine protects against liver injure induced by carbon tetrachloride via activation of the nrf2/ho-1 pathway. Int. J. Clin. Exp. Pathol. 2015, 8, 8655-8662.

21. Mohammed, A.; Abd Al Haleem, E.N.; El-Bakly, W.M.; El-Demerdash, E. Deferoxamine alleviates liver fibrosis induced by ccl4 in rats. Clin. Exp. Pharmacol. Physiol. 2016, 43, 760-768. [CrossRef]

22. Liang, W.; Huang, X.; Chen, W. The effects of baicalin and baicalein on cerebral ischemia: A review. Aging Dis. 2017, 8, 850-867. [CrossRef] [PubMed]

23. Sahu, B.D.; Kumar, J.M.; Sistla, R. Baicalein, a bioflavonoid, prevents cisplatin-induced acute kidney injury by up-regulating antioxidant defenses and down-regulating the mapks and nf-kappa b pathways. PLoS ONE 2015, 10, e0134139.

24. de Oliveira, M.R.; Nabavi, S.F.; Habtemariam, S.; Orhan, I.E.; Daglia, M.; Nabavi, S.M. The effects of baicalein and baicalin on mitochondrial function and dynamics: A review. Pharmacol. Res. 2015, 100, 296-308. [CrossRef]

25. Zhang, Z.; Cui, W.; Li, G.; Yuan, S.; Xu, D.; Hoi, M.P.; Lin, Z.; Dou, J.; Han, Y.; Lee, S.M. Baicalein protects against 6-ohda-induced neurotoxicity through activation of keap1/nrf2/ho-1 and involving pkcalpha and pi3k/akt signaling pathways. J. Agric. Food Chem. 2012, 60, 8171-8182. [CrossRef] [PubMed]

26. Lai, C.C.; Huang, P.H.; Yang, A.H.; Chiang, S.C.; Tang, C.Y.; Tseng, K.W.; Huang, C.H. Baicalein, a component of scutellaria baicalensis, attenuates kidney injury induced by myocardial ischemia and reperfusion. Planta Med. 2016, 82, 181-189. [CrossRef]

27. Xiao, T.; Cui, Y.; Ji, H.; Yan, L.; Pei, D.; Qu, S. Baicalein attenuates acute liver injury by blocking nlrp3 inflammasome. Biochem. Biophys. Res. Commun. 2021, 534, 212-218. [CrossRef]

28. Dai, C.; Tang, S.; Wang, Y.; Velkov, T.; Xiao, X. Baicalein acts as a nephroprotectant that ameliorates colistin-induced nephrotoxicity by activating the antioxidant defence mechanism of the kidneys and down-regulating the inflammatory response. J. Antimicrob. Chemother. 2017, 72, 2562-2569. [CrossRef]

29. Zhou, H.C.; Wang, H.; Shi, K.; Li, J.M.; Zong, Y.; Du, R. Hepatoprotective effect of baicalein against acetaminophen-induced acute liver injury in mice. Molecules 2018, 24, 131. [CrossRef]

30. Dixon, S.J.; Lemberg, K.M.; Lamprecht, M.R.; Skouta, R.; Zaitsev, E.M.; Gleason, C.E.; Patel, D.N.; Bauer, A.J.; Cantley, A.M.; Yang, W.S.; et al. Ferroptosis: An iron-dependent form of nonapoptotic cell death. Cell 2012, 149, 1060-1072. [CrossRef]

31. Yamada, N.; Karasawa, T.; Kimura, H.; Watanabe, S.; Komada, T.; Kamata, R.; Sampilvanjil, A.; Ito, J.; Nakagawa, K.; Kuwata, H.; et al. Ferroptosis driven by radical oxidation of n-6 polyunsaturated fatty acids mediates acetaminophen-induced acute liver failure. Cell Death Dis. 2020, 11, 144. [CrossRef] [PubMed] 
32. Popović, D.; Kocić, G.; Katić, V.; Zarubica, A.; Veličković, L.J.; Ničković, V.P.; Jović, A.; Veljković, A.; Petrović, V.; Rakić, V.; et al. Anthocyanins protect hepatocytes against ccl(4)-induced acute liver injury in rats by inhibiting pro-inflammatory mediators, polyamine catabolism, lipocalin-2, and excessive proliferation of kupffer cells. Antioxidants 2019, 8, 451. [CrossRef] [PubMed]

33. Stine, J.G.; Intagliata, N.; Shah, N.L.; Argo, C.K.; Caldwell, S.H.; Lewis, J.H.; Northup, P.G. Hepatic decompensation likely attributable to simeprevir in patients with advanced cirrhosis. Dig. Dis. Sci. 2015, 60, 1031-1035. [CrossRef]

34. Cragg, G.M.; Newman, D.J. Natural products: A continuing source of novel drug leads. Biochim. Biophys. Acta 2013, 1830, 3670-3695. [CrossRef] [PubMed]

35. Shi, J.; Aisaki, K.; Ikawa, Y.; Wake, K. Evidence of hepatocyte apoptosis in rat liver after the administration of carbon tetrachloride. Am. J. Pathol. 1998, 153, 515-525. [CrossRef]

36. Wu, S.J.; Lin, Y.H.; Chu, C.C.; Tsai, Y.H.; Chao, J.C. Curcumin or saikosaponin a improves hepatic antioxidant capacity and protects against ccl4-induced liver injury in rats. J. Med. Food 2008, 11, 224-229. [CrossRef]

37. Dai, C.; Li, J.; Tang, S.; Li, J.; Xiao, X. Colistin-induced nephrotoxicity in mice involves the mitochondrial, death receptor, and endoplasmic reticulum pathways. Antimicrob. Agents Chemother. 2014, 58, 4075-4085. [CrossRef]

38. Chen, C.; Cai, C.; Lin, H.; Zhang, W.; Peng, Y.; Wu, K. Baicalein protects renal tubular epithelial cells againsthypoxia-reoxygenation injury. Ren. Fail. 2018, 40, 603-610. [CrossRef]

39. Sahu, B.D.; Kumar, J.M.; Kuncha, M.; Borkar, R.M.; Srinivas, R.; Sistla, R. Baicalein alleviates doxorubicin-induced cardiotoxicity via suppression of myocardial oxidative stress and apoptosis in mice. Life Sci. 2016, 144, 8-18. [CrossRef]

40. Perez, C.A.; Wei, Y.; Guo, M. Iron-binding and anti-fenton properties of baicalein and baicalin. J. Inorg. Biochem. 2009, 103, 326-332. [CrossRef]

41. Dai, C.; Li, B.; Zhou, Y.; Li, D.; Zhang, S.; Li, H.; Xiao, X.; Tang, S. Curcumin attenuates quinocetone induced apoptosis and inflammation via the opposite modulation of nrf2/ho-1 and nf-kb pathway in human hepatocyte 102 cells. Food Chem. Toxicol. 2016, 95, 52-63. [CrossRef] [PubMed]

42. Wu, Y.L.; Lian, L.H.; Wan, Y.; Nan, J.X. Baicalein inhibits nuclear factor-kappab and apoptosis via c-flip and mapk in d-galn/lps induced acute liver failure in murine models. Chem. Biol. Interact. 2010, 188, 526-534. [CrossRef]

43. Ahmad, R.; Rasheed, Z.; Ahsan, H. Biochemical and cellular toxicology of peroxynitrite: Implications in cell death and autoimmune phenomenon. Immunopharmacol. Immunotoxicol. 2009, 31, 388-396. [CrossRef]

44. Choi, E.O.; Jeong, J.W.; Park, C.; Hong, S.H.; Kim, G.Y.; Hwang, H.J.; Cho, E.J.; Choi, Y.H. Baicalein protects c6 glial cells against hydrogen peroxide-induced oxidative stress and apoptosis through regulation of the nrf2 signaling pathway. Int. J. Mol. Med. 2016, 37, 798-806. [CrossRef]

45. Dai, C.; Tang, S.; Deng, S.; Zhang, S.; Zhou, Y.; Velkov, T.; Li, J.; Xiao, X. Lycopene attenuates colistin-induced nephrotoxicity in mice via activation of the nrf2/ho-1 pathway. Antimicrob. Agents Chemother. 2015, 59, 579-585. [CrossRef] [PubMed]

46. Dai, C.; Chen, X.; Li, J.; Comish, P.; Kang, R.; Tang, D. Transcription factors in ferroptotic cell death. Cancer Gene Ther. 2020, 27, 646-656. [CrossRef]

47. Yeh, C.H.; Ma, K.H.; Liu, P.S.; Kuo, J.K.; Chueh, S.H. Baicalein decreases hydrogen peroxide-induced damage to ng108-15 cells via upregulation of nrf2. J. Cell Physiol. 2015, 230, 1840-1851. [CrossRef]

48. Shi, L.; Hao, Z.; Zhang, S.; Wei, M.; Lu, B.; Wang, Z.; Ji, L. Baicalein and baicalin alleviate acetaminophen-induced liver injury by activating nrf2 antioxidative pathway: The involvement of erk1/2 and pkc. Biochem. Pharmacol. 2018, 150, 9-23. [CrossRef] [PubMed]

49. Jeong, J.Y.; Cha, H.J.; Choi, E.O.; Kim, C.H.; Kim, G.Y.; Yoo, Y.H.; Hwang, H.J.; Park, H.T.; Yoon, H.M.; Choi, Y.H. Activation of the nrf2/ho-1 signaling pathway contributes to the protective effects of baicalein against oxidative stress-induced DNA damage and apoptosis in hei193 schwann cells. Int. J. Med. Sci. 2019, 16, 145-155. [CrossRef]

50. Sun, X.; Ou, Z.; Chen, R.; Niu, X.; Chen, D.; Kang, R.; Tang, D. Activation of the p62-keap1-nrf2 pathway protects against ferroptosis in hepatocellular carcinoma cells. Hepatology 2016, 63, 173-184. [CrossRef]

51. Dai, C.; Zhang, D.; Li, J.; Li, J. Effect of colistin exposure on calcium homeostasis and mitochondria functions in chick cortex neurons. Toxicol. Mech. Methods 2013, 23, 281-288. [CrossRef] [PubMed]

52. Jang, S.; Yu, L.R.; Abdelmegeed, M.A.; Gao, Y.; Banerjee, A.; Song, B.J. Critical role of c-jun n-terminal protein kinase in promoting mitochondrial dysfunction and acute liver injury. Redox Biol. 2015, 6, 552-564. [CrossRef] [PubMed]

53. Yu, Z.; Li, Q.; Wang, Y.; Li, P. A potent protective effect of baicalein on liver injury by regulating mitochondria-related apoptosis. Apoptosis 2020, 25, 412-425. [CrossRef]

54. Choi, Y.H. Activation of the nrf2/ho-1 signaling pathway contributes to the protective effects of coptisine against oxidative stress-induced DNA damage and apoptosis in hacat keratinocytes. Gen. Physiol. Biophys. 2019, 38, 281-294. [CrossRef]

55. Zhang, S.; Lu, B.; Han, X.; Xu, L.; Qi, Y.; Yin, L.; Xu, Y.; Zhao, Y.; Liu, K.; Peng, J. Protection of the flavonoid fraction from rosa laevigata michx fruit against carbon tetrachloride-induced acute liver injury in mice. Food Chem. Toxicol. 2013, 55, 60-69. [CrossRef]

56. Shi, H.; Han, W.; Shi, H.; Ren, F.; Chen, D.; Chen, Y.; Duan, Z. Augmenter of liver regeneration protects against carbon tetrachloride-induced liver injury by promoting autophagy in mice. Oncotarget 2017, 8, 12637. [CrossRef]

57. Cao, M.; Wang, H.; Guo, L.; Yang, S.; Liu, C.; Khor, T.O.; Yu, S.; Kong, A.N. Dibenzoylmethane protects against ccl4-induced acute liver injury by activating nrf2 via jnk, ampk, and calcium signaling. AAPS J. 2017, 19, 1703-1714. [CrossRef] 
58. Yang, B.Y.; Zhang, X.Y.; Guan, S.W.; Hua, Z.C. Protective effect of procyanidin b2 against ccl4-induced acute liver injury in mice. Molecules 2015, 20, 12250-12265. [CrossRef]

59. Morgan, M.J.; Liu, Z.G. Crosstalk of reactive oxygen species and nf-kappab signaling. Cell Res. 2011, 21, 103-115. [CrossRef]

60. Xiang, L.; Hu, Y.F.; Wu, J.S.; Wang, L.; Huang, W.G.; Xu, C.S.; Meng, X.L.; Wang, P. Semi-mechanism-based pharmacodynamic model for the anti-inflammatory effect of baicalein in lps-stimulated raw264.7 macrophages. Front. Pharmacol. 2018, 9, 793. [CrossRef] [PubMed]

61. Sun, H.; Che, Q.M.; Zhao, X.; Pu, X.P. Antifibrotic effects of chronic baicalein administration in a ccl4 liver fibrosis model in rats. Eur. J. Pharmacol. 2010, 631, 53-60. [CrossRef]

62. Huang, H.L.; Wang, Y.J.; Zhang, Q.Y.; Liu, B.; Wang, F.Y.; Li, J.J.; Zhu, R.Z. Hepatoprotective effects of baicalein against ccl(4)-induced acute liver injury in mice. World J. Gastroenterol. 2012, 18, 6605-6613. [CrossRef] [PubMed]

63. Zahedi, K.; Barone, S.L.; Xu, J.; Steinbergs, N.; Schuster, R.; Lentsch, A.B.; Amlal, H.; Wang, J.; Casero, R.A., Jr.; Soleimani, M. Hepatocyte-specific ablation of spermine/spermidine-n1-acetyltransferase gene reduces the severity of ccl4-induced acute liver injury. Am. J. Physiol. Gastrointest. Liver Physiol. 2012, 303, G546-G560. [CrossRef] [PubMed]

64. Huang, G.J.; Deng, J.S.; Chiu, C.S.; Liao, J.C.; Hsieh, W.T.; Sheu, M.J.; Wu, C.H. Hispolon protects against acute liver damage in the rat by inhibiting lipid peroxidation, proinflammatory cytokine, and oxidative stress and downregulating the expressions of inos, cox-2, and mmp-9. Evid. Based Complement. Alternat. Med. 2012, 2012, 480714. [CrossRef] [PubMed]

65. Xie, Y.; Song, X.; Sun, X.; Huang, J.; Zhong, M.; Lotze, M.T.; Zeh, H.J.R.; Kang, R.; Tang, D. Identification of baicalein as a ferroptosis inhibitor by natural product library screening. Biochem. Biophys. Res. Commun. 2016, 473, 775-780. [CrossRef]

66. Yang, W.S.; SriRamaratnam, R.; Welsch, M.E.; Shimada, K.; Skouta, R.; Viswanathan, V.S.; Cheah, J.H.; Clemons, P.A.; Shamji, A.F.; Clish, C.B.; et al. Regulation of ferroptotic cancer cell death by gpx4. Cell 2014, 156, 317-331. [CrossRef] [PubMed]

67. Fang, X.; Wang, H.; Han, D.; Xie, E.; Yang, X.; Wei, J.; Gu, S.; Gao, F.; Zhu, N.; Yin, X.; et al. Ferroptosis as a target for protection against cardiomyopathy. Proc. Natl. Acad. Sci. USA 2019, 116, 2672-2680. [CrossRef]

68. Li, Q.; Li, Q.Q.; Jia, J.N.; Sun, Q.Y.; Zhou, H.H.; Jin, W.L.; Mao, X.Y. Baicalein exerts neuroprotective effects in fecl3-induced postraumatic epileptic seizures via suppressing ferroptosis. Front. Pharmacol. 2019, 10, 638. [CrossRef]

69. Tesfay, L.; Paul, B.T.; Konstorum, A.; Deng, Z.; Cox, A.O.; Lee, J.; Furdui, C.M.; Hegde, P.; Torti, F.M.; Torti, S.V. Stearoyl-coa desaturase 1 protects ovarian cancer cells from ferroptotic cell death. Cancer Res. 2019, 79, 5355-5366. [CrossRef]

70. Lu, M.J.; Chen, Y.S.; Huang, H.S.; Ma, M.C. Hypoxic preconditioning protects rat hearts against ischemia-reperfusion injury via the arachidonate12-lipoxygenase/transient receptor potential vanilloid 1 pathway. Basic Res. Cardiol. 2014, 109, 414. [CrossRef]

71. Xue, Y.; Deng, Q.; Zhang, Q.; Ma, Z.; Chen, B.; Yu, X.; Peng, H.; Yao, S.; Liu, J.; Ye, Y.; et al. Gigantol ameliorates ccl4-induced liver injury via preventing activation of jnk/cpla2/12-lox inflammatory pathway. Sci. Rep. 2020, 10, 22265. [CrossRef] [PubMed]

72. Li, M.; Shi, A.; Pang, H.; Xue, W.; Li, Y.; Cao, G.; Yan, B.; Dong, F.; Li, K.; Xiao, W.; et al. Safety, tolerability, and pharmacokinetics of a single ascending dose of baicalein chewable tablets in healthy subjects. J. Ethnopharmacol. 2014, 156, 210-215. [CrossRef] [PubMed]

73. Pang, H.; Xue, W.; Shi, A.; Li, M.; Li, Y.; Cao, G.; Yan, B.; Dong, F.; Xiao, W.; He, G.; et al. Multiple-ascending-dose pharmacokinetics and safety evaluation of baicalein chewable tablets in healthy chinese volunteers. Clin. Drug Investig. 2016, 36, 713-724. [CrossRef] [PubMed] 